\title{
EMBRYOGENY AND SPOROGENESIS IN REBOULIA HEMISPHAERICA
}

\author{
ARthur W. HaUPT \\ (WITH PLATE XXXIII AND ELEVEN FIGURES)
}

The present paper is a continuation of the writer's earlier morphological study of Reboulia (5). The systematic position of the genus and its phylogenetic relationships, as revealed by the structure and development of the gametophyte and sex organs, has already been discussed. To determine the affinities of Reboulia to other Marchantiaceae, as shown by the development of its sporophyte, was the purpose for which the present investigation was undertaken.

\section{Material}

Material furnished by Dr. W. J. G. LAND for the earlier study, and collected by him at Rome, Indiana, served to illustrate a number of stages in the embryogeny. Most of the material, however, was collected by the writer during the autumn of I9I9 and the spring of 1920 in the vicinity of Hamilton, Hancock County, Illinois. In this locality Reboulia occurs in abundance beneath moist ledges of sandstone. Material was also obtained from the region about Dakota, Illinois, through the kindness of Mr. EARL L. LAMBERT.

\section{Embryo}

The first division of the fertilized egg of Reboulia is invariably accompanied by a transverse wall (figs. I, 2), the two segments being approximately equal in size. From a careful study of later stages the conclusion is reached that the epibasal segment gives rise to both the seta and capsule, while the hypobasal segment forms the foot. In a recent preliminary paper on Reboulia, WOODBURN (8) is in agreement with this interpretation. The next division results in the formation of a transverse wall in the epibasal cell which differentiates the cells which are to form the seta and capsule (fig. 3 ). A tier of 3 horizontally superimposed cells is thus developed. The lowest cell may again divide by a vertical wall (fig. 3), but more 
commonly the uppermost cell divides again transversely before the appearance of the vertical wall in the basal cell, so that the young embryo consists of 4 superimposed cells (fig. 4). The latter condition has also been noted by WoodBuRn.

The formation of 3 transverse walls in the early embryo of Reboulia represents a behavior quite different from that of the other Marchantiaceae which have been studied. The appearance
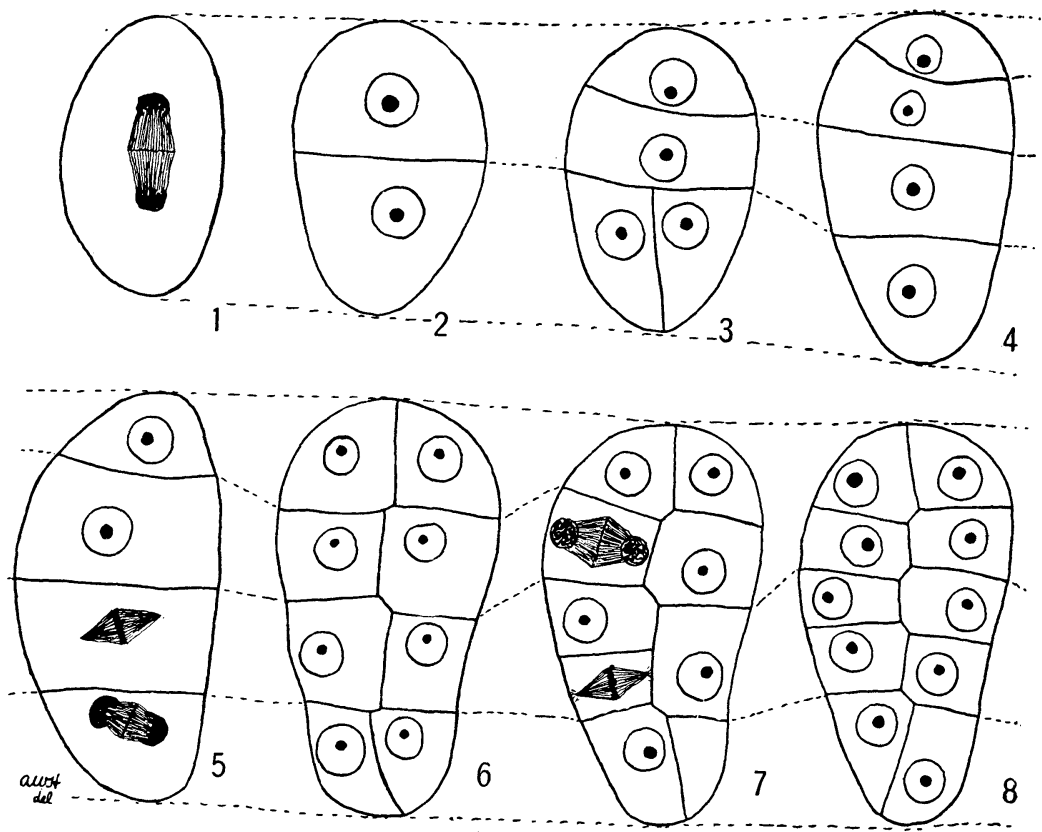

Figs. I-8. - Stages in development of embryo; $\times 475$.

of 2 vertical walls which intersect each other, after the first transverse division of the fertilized egg, has been shown by KienitzGerloff (6) and DuRAND (3) to be a constant feature of Marchantia. CAMPBELl (I) has demonstrated the regular formation of an octant in the early embryo of Fimbriaria californica, while CAvers (2) has claimed that a similar condition prevails in Reboulia. KienitzGERLOFF has also stated that the embryos of Preissia and Grimaldia develop like those of Marchantia, but his figures show no early stages, and are accordingly unconvincing. Following the 
formation of the 3 transverse walls, vertical walls appear at right angles to each other in each horizontal tier (fig. 6), although the lowest cell may divide vertically before the appearance of the third transverse wall, as previously stated. These vertical divisions begin at the lower end of the embryo (fig. 5), a feature which is also noted by WoodBurN's figures. Additional cross-walls then come in, and an embryo consisting of $5^{-7}$ tiers of cells is thereby formed (figs. 7,8 ). This was a very common stage seen in the preparations. The additional transverse divisions occur chiefly in the upper part of the embryo. WoODBURN has observed the occasional formation of

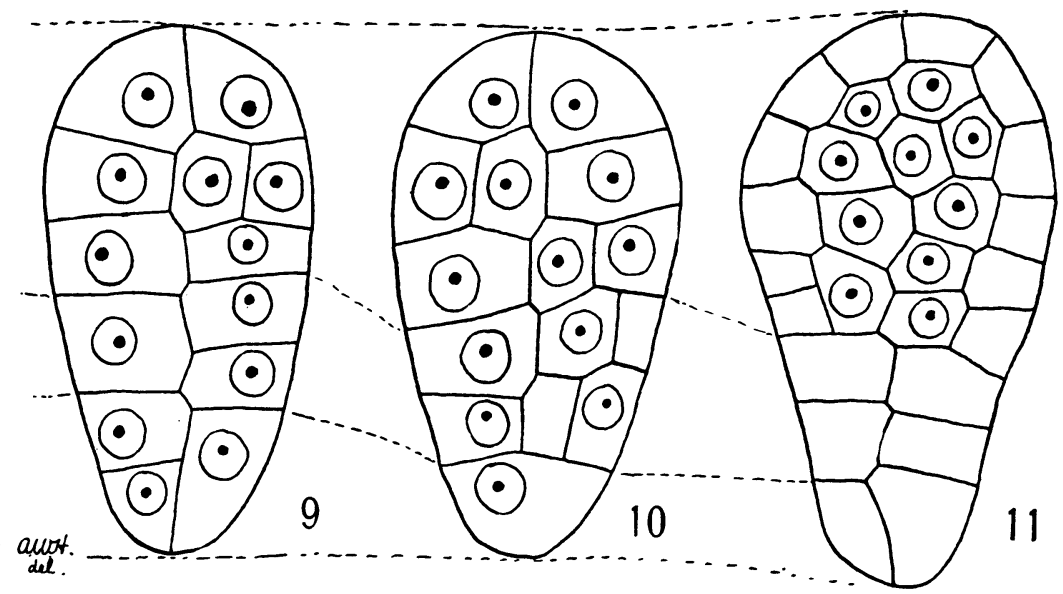

Figs. 9-II.-Older stages in embryogeny; $\times_{475}$.

a triangular-shaped apical cell in the young embryo, and often of both triangular apical and basal cells. The writer has seen stages similar to those figured by WOODBURN, but found that the triangular form of the uppermost cell invariably resulted from an obliquely cut section. A truly median section has never revealed the presence of a triangular apical cell.

With the definite establishment of the vertical walls in the embryo, both transverse and vertical divisions occur chiefly in its upper portion (fig. 7, 9, 10), and finally the sporogenous tissue is delimited from the amphithecium (fig. II). Further development is typical of that of other Marchantiaceae which have been investigated. 
With the development of the sporogenous tissue and the cells of the foot, the young sporophyte gradually assumes a dumb-bell shape. The seta remains short throughout the entire history of the sporophyte. The calyptra, formed entirely from the venter of the archegonium, is $3-5$ cells thick in this dumb-bell-like stage of the sporophyte. As development proceeds, the margins of the receptacle lobes grow up around the sporophyte to form a simple 2-valved involucre. No perianth is developed, as in certain other genera of the Marchantiaceae. The receptacle stalk is very short at a stage in which the sporophytes are developed as far as has been described, and they pass the winter in this condition.

\section{Sporogenesis}

In the early spring, about the last week in March in the region where this material was collected, the receptacle stalk begins to elongate, and further development of the sporogenous tissue takes place. In the early spring the sporogenous cells give no indication of which are to form spore mother cells and which elaters (fig. 12), but by the first part of May the walls separating the protoplasts of the sporogenous tissue break down and form an abundance of mucilage, and the young spore mother cells and elaters are clearly differentiated (fig. I3).

A striking feature of the sporogenesis of Reboulia is shown by the fact that the spore mother and elater primordial cells are derived from the undifferentiated sporogenous tissue by the same number of cell divisions. Thus an elater is not homologous with a row of spore mother cells, as in Marchantia, but with a single spore mother cell. Potentially sporogenous tissue is thus diverted to form elaters later than in Marchantia, and in this respect the sporophyte of Reboulia is primitive.

With the breaking down of the sporogenous cell walls, the protoplasts of the young spore mother cells become withdrawn within the cell cavities and assume an amoeboid form, while those of the young elaters become elongated (fig. I3). This behavior was constant in all of the preparations examined, and in material collected in both of the localities in Illinois to which reference has been made. 
Miss McCormick (7) has shown in Symphyogyna that the spore mother cells assume an amoeboid form in connection with the development of the 4 lobes which characterize the spore mother cells of the Jungermanniales, and the same behavior has been observed in Pallavicinia (4). The assumption of an amoeboid character by the young spore mother cells of Reboulia, in which no lobes develop, clearly demonstrates that this behavior is not necessarily related to the formation of lobed spore mother cells.

With the gradual dissolution of the old spore walls, the spore mother cells lose their amoeboid form and become globular, gradually growing larger and becoming increasingly more dense by the accumulation of food material (figs. 14, I5). Thus the writer is inclined to regard the amoeboid development as a feature related to the nourishment of the spore mother cells. Their increase in size and globular form is certainly not due to the release of pressure upon the cells of the sporogenous tissue occasioned by the increased size of the capsular cavity, for no such enlargement or acquisition of food material is shown by the elaters.

The mucilaginous substance around the spore mother cells and elaters presents a foamlike appearance as these changes are going on, and becomes increasingly less dense. Both the spore mother cells and elaters form a new cellulose wall after the former have reached their maximum size (fig. I5). The new spore wall around the spore mother cells becomes thick and is differentiated into a thin intine and a heavy exine. Their protoplasts are now extremely dense, so that even in sections cut to a thickness of $3 \mu$ it is very difficult to study nuclear details.

With the development of the walls in the spore mother cell to form the tetrad, a thin epispore is laid down (fig. I6). The elaters, which elongate considerably as the spore mother cells develop, have merely a thin cellulose wall when the tetrad stage in sporogenesis is reached, and their protoplasm is slightly withdrawn inside of the cell cavity.

With the separation of the spores from their tetrads, all of the mucilage is gone. The epispore develops prominences by a process of outbulging (fig. I7), so that the mature spore when seen from the surface is described as having a thick "tuberculate" epispore. 
The protoplasm of the elaters becomes further withdrawn from the cell wall, and a double spiral band appears in the form of a local thickening on the inside of the elater wall. Finally all of the protoplasm is lost, as its substance seems to contribute to the further development of the spiral band.

The relation between the protoplasmic contents of the elaters and the formation of their spiral band was studied in all available stages in their development. In no case was a behavior observed such as has been described by CAMPBELl (I) for Fimbriaria californica:

The elaters are at first elongated thin-walled cells with a distinct although small nucleus, and nearly uniformly granular cytoplasm. As they grow the cytoplasm loses this uniform appearance, and a careful examination, especially of sections, shows that the granular part of the cytoplasm begins to form a spiral band, recalling somewhat the chlorophyll band of Spirogyra. This is the beginning of the characteristic spiral thickening of the cell wall, and while at first irregular, the arrangement of the granular matter becomes more definite, and following the line of this spiral band of granules in the cytoplasm, there is formed upon the inner surface of the wall the regular spiral band of the complete elater.

The mature elaters average slightly over $\mathrm{I} .0 \mathrm{~mm}$. in length, the longest one measured being $\mathrm{I} .36 \mathrm{~mm}$. and the shortest $0.94 \mathrm{~mm}$. The mature spores average $70-80 \mu$ in diameter. The mature sporophyte reaches a length of $1.6-2.0 \mathrm{~mm}$. The capsule is oval or slightly obovate; its wall is but I cell thick except near the apex, where a cap 3 or 4 layers of cells in thickness is formed. The outer wall cells develop simple annular and half-ring fibers. Dehiscence of the capsule was not observed, but it is probable that the apical cap comes off. The seta of the mature sporophyte is comparatively very short, and the foot is bulbous, never anchor-like.

\section{Summary}

I. The embryo of Reboulia develops without the formation of an octant stage characteristic of certain other Marchantiaceae.

2. The first transverse wall in the fertilized egg separates the cell which is to form the foot from that which is to form the seta and capsule. Four horizontally superimposed cells are usually formed, each new division occurring in the outermost segment. Of 
these the lowest cell forms the foot, the next one the seta, and the upper two the capsule.

3. The sporogenous tissue is formed relatively early in the history of the sporophyte.

4. In the development of spore mother cells and elaters the walls around the sporogenous cells become mucilaginous, the protoplasts of the former assume an amoeboid form and finally become large and spherical, while those of the latter are slender and elongated. A new cell wall is laid down around both spore mother cells and elaters.

5. The assumption of an amoeboid form by the young spore mother cells is a feature related to their nutrition.

6. An elater in Reboulia is homologous with a single spore mother cell, and not with a row of them.

7. The exine and intine are differentiated in the tetrad stage, and the epispore has begun to develop. The formation of a double spiral band on the elaters is accompanied by a condensation and ultimate disappearance of the protoplasm.

8. The short seta and bulbous foot are primitive features of the genus.

St. LAWRENCE UNIVERSITY

Canton, N.Y.

\section{LITERATURE CITED}

I. Campbell, D. H., Mosses and ferns. New York. I905.

2. Cavers, F., Contributions to the biology of the Hepaticae. Part I. Targionia, Reboulia, Preissia, Monoclea. Leeds and London. I904.

3. DuRand, E. J., The development of the sex organs and sporogonium of Marchantia polymorpha. Bull. Torr. Bot. Club 35:321-335. I908.

4. Haupt, A. W., A morphological study of Pallavicinia Lyellii. Bот. Gaz. $66: 524-533$. I9I8.

5. - - Gametophyte and sex organs of Reboulia hemisphaerica. Вот. GAz. 7I:6I-74. I92I.

6. Kienitz-Gerloff, F., Vergleichende Untersuchungen über die Entwicklungsgeschichte des Lebermoossporogons. Bot. Zeit. 32:16I-172; 33:777782. 1875 .

7. McCormick, Florence A., A study of Symphyogyna aspera. Bot. Gaz. 58:40I-4I8. I9I4.

8. Woodburn. W. L., Preliminary notes on the embryology of Reboulia hemisphaerica. Bull. Torr. Bot. Club 46:46I-464. I920. 

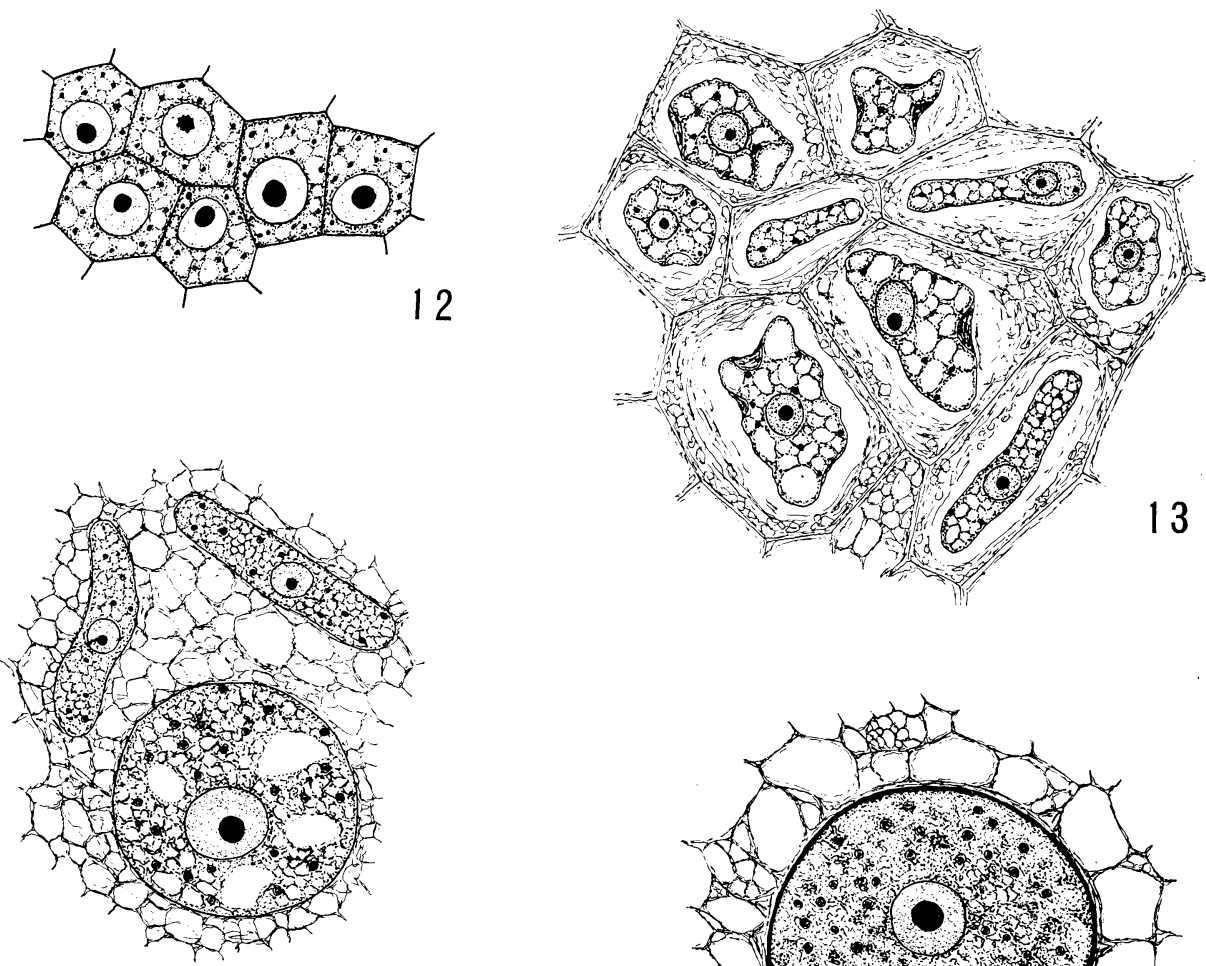

14
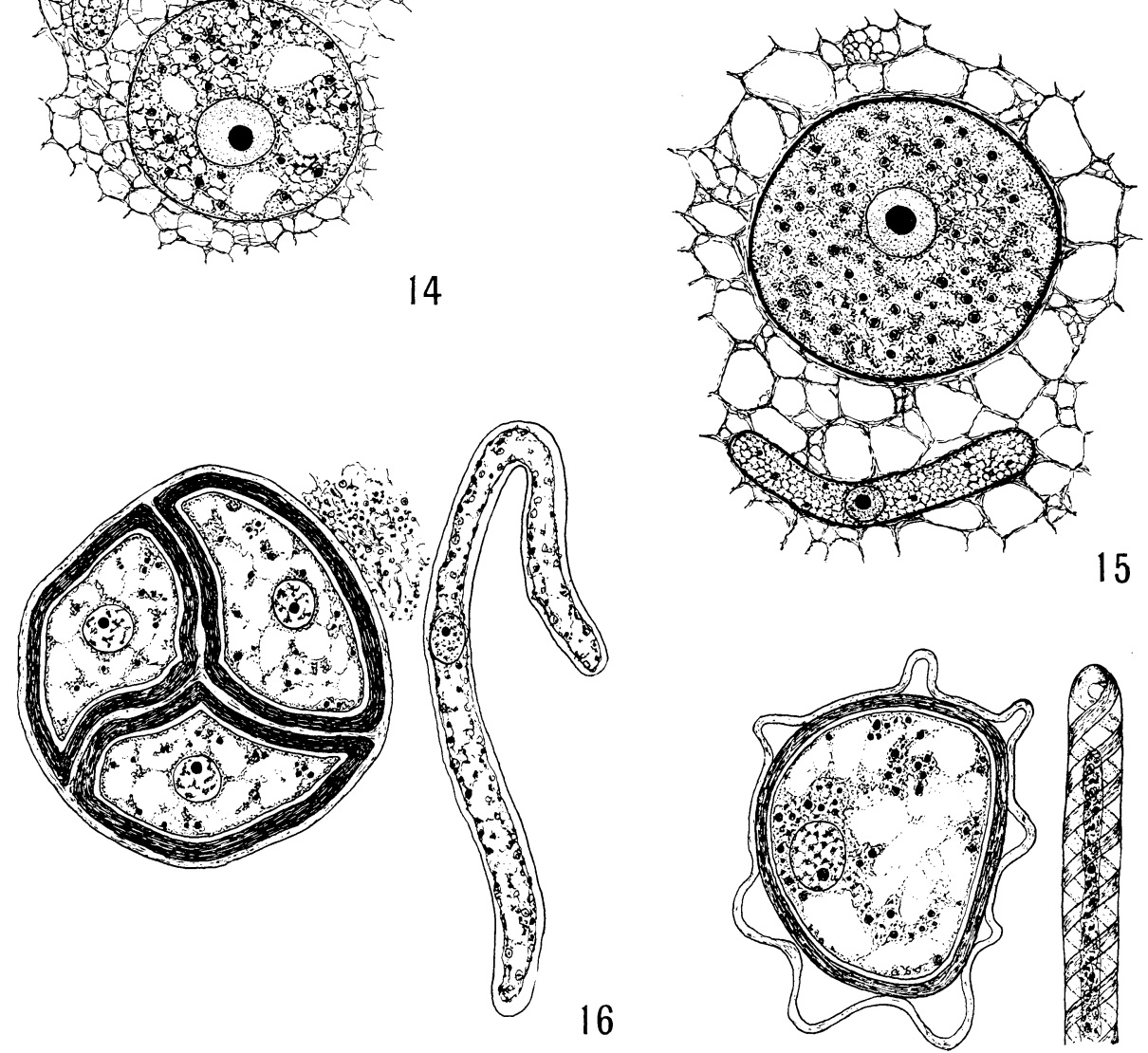

16
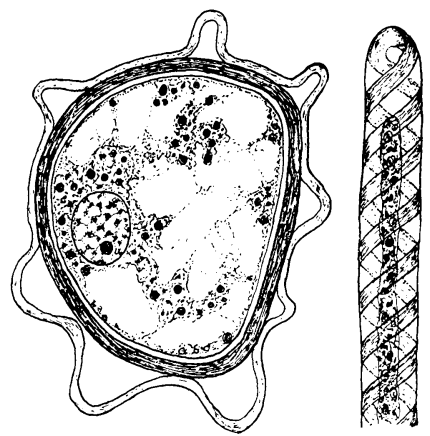

HAUPT on REBOULIA 


\section{EXPLANATION OF PLATE XXXIII}

FIG. I2.- Sporogenous tissue; $\times_{720}$.

FIG. I3.-Young spore mother cells in amoeboid stage and young elaters; $\times 720$.

Fig. 14.-Older stage showing development of cell walls around spore mother cells and elaters; $\times_{720}$.

FIG. 15 .-Older stage of same; $\times_{720}$.

FIG. 16.-Spore tetrad showing development of spore coats and elater; $\times 720$.

FIG. I 7.-Nearly mature spore and elater showing development of epispore on former and double spiral band on latter; $\times 720$. 